\title{
MENINGKATKAN ASPEK MENDENGARKAN DENGAN PENDEKATAN KOMUNIKATIF DAN METODE LEBAH BERDENGUNG PADA SISWA KELAS I SD
}

\author{
Syarifah Syapinah \\ Guru SDN 10 Mungguk Ibul \\ Emai: syarifahsyapinahsdn10munggukibul@gmail.com
}

\begin{abstract}
Abstrak
Pada awal pembelajaran bahasa Indonesia aspek mendengarkan di kelas I SD Negeri 10 Mungguk Ibul, Kecamatan Sukadana, Kabupaten Kayong Utara Semester Ganjil tahun pelajaran 2018/2019, menemui beberapa hambatan. Penyebab-penyebabnya dapat berasal dari siswa, guru, serta sarana yang kurang memadai. Dari masalah di atas peneliti menganalisis bahwa masalah yang perlu ditangani lebih dahulu adalah mengganti dongeng tentang kerajaan sebelum perbaikan dengan dongeng yang lebih menarik perhatian anak, seperti dongeng tentang binatang serta pemilihan pendekatan dan metode pembelajaran yang lebih tepat yaitu pendekatan komunikatif dan metode lebah berdengung. Berdasarkan data hasil tes dan diskusi dengan teman sejawat, perbaikan pembelajaran tentang bercerita ada peningkatan pada masing-masing siklus. Baik peningkatan ratarata prestasi belajar yang cukup signifikan, peningkatan apresiasi siswa terhadap pembelajaran.
\end{abstract}

\section{Kata Kunci : Aspek Mendengarkan, Pendekatan Komunikatif, Metode Lebah Berdengung}

\section{PENDAHULUAN}

Keberhasilan dunia pendidikan memiliki sistem yang relevan dengan pembangunan, baik fisik maupun mental. Adaptasi dan antisipasi terhadap perkembangan ilmu pengetahuan dan teknologi yang dibina secara sistematik dan berkesinambungan. Dengan demikian untuk memecahkan masalah harus dimulai dengan peningkatan dan pemerataan kualitas tenaga pengajar dipendidikan dasar.

Pendidikan merupakan wahana pokok bagi pengembangan kualitas sumber daya manusia, karena itu upaya peningkatan mutu pendidikan dasar perlu mendapat perhatian yang sungguhsungguh. Lebih-lebih sekolah dasar yang merupakan pondasi bagi seluruh jenjang pendidikan.

Guru dalam mengajar di kelas sering dihadapkan pada berbagai masalah dalam kegiatan pembelajaran. Hal ini sangat disadari oleh guru sebab seorang guru dalam menyampaikan pelajaran kepada siswa tentunya memiliki kekurangan dan kelebihan, walaupun demikian setiap guru selalu memiliki harapan agar siswanya pada akhir pembelajaran mampu memahami materi yang telah diberikan, sekaligus berprestasi yang dibuktikan dengan hasil belajar yang maksimal. Dalam kerangka inilah seorang guru dalam proses pembelajarannya selalu mendesain perencanaan pembelajarannya yang dapat memberikan kontribusi yang positif terhadap kondisi siswa sehingga materi pelajaran yang diberikan dapat diserap oleh siswa, dan basil prestasi yang dicapai siswa dapat memuaskan.

Demikian juga dalam proses pembelajaran, guru juga dihadapkan pada kenyataan selalu menemui keanekaragaman tingkat kemampuan siswa. Keanekaragaman tingkat kemampuan ini akan membuat tingkat penguasaan belajar yang berbeda antara siswa yang satu dengan siswa yang lain, sehingga ada siswa yang mencapai prestasi hasil belajar yang amat baik dalam arti menguasai seluruh bahan pelajaran. Tetapi ada pula siswa yang memang tergolong memiliki kemampuan akademik yang kurang. Jika siswa yang tidak mampu mengusai bahan pelajaran secara tuntas ini dibiarkan terus-menerus, akan berdampak negatif terhadap penguasaan bahan pelajaran yang belum mampu dikuasai menjadikan siswa kerepotan untuk menerima materi pelajaran berikutnya.

Pada awal pembelajaran bahasa Indonesia aspek mendengarkan di kelas I SD Negeri 10 Mungguk Ibul, Kecamatan Sukadana, Kabupaten Kayong Utara Semester Ganjil tahun pelajaran 2018/2019, menemui beberapa hambatan. 
Penyebab-penyebabnya dapat berasal dari siswa, guru, serta sarana yang kurang memadai.

Pada pelaksanaan pembelajaran Bahasa Indonesia pada aspek mendengarkan di kelas I SD Negeri 10 Mungguk Ibul, Kecamatan Sukadana, Kabupaten Kayong Utara Semester Ganjil tahun pelajaran 2018/2019, mengalami kegagalan. Hal ini ditunjukkan dari 27 siswa hanya 4 orang siswa yang mencapai nilai di atas 75 sehingga presentase ketuntasan belajar hanya $14,8 \%$. Oleh karena itu penulis bermaksud memperbaikinya melalui Penelitian Tindakan Kelas.

Dari pembelajaran mendongeng ini dapat diidentifikasi berbagai masalah sebagai berikut : (1) Guru saat mendiskripsikan benda sekitar kurang menarik. (2) Guru mendongeng tentang kerajaan yang kurang diminati oleh siswa. (3) Saat mendongeng guru tidak menggunakan media yang dapat menarik siswa. (4) Guru mendongeng dengan suara kurang menarik perhatian siswa. (5) Siswa mendengarkan tapi kurang antusias. (6) Siswa tidak dapat menceritakan dongeng yang telah didengarnya dari guru kepada temannya. (7) Setelah mendengarkan guru mendongeng siswa tidak dapat menyebutkan isi dongeng. Semua data yang didapat di atas dapat diperbaiki melalui penelitian tindakan kelas.

Dari masalah di atas peneliti menganalisis bahwa masalah yang perlu ditangani lebih dahulu adalah mengganti dongeng tentang kerajaan sebelum perbaikan dengan dongeng yang lebih menarik perhatian anak, seperti dongeng tentang binatang serta pemilihan pendekatan dan metode pembelajaran yang lebih tepat yaitu pendekatan komunikatif dan metode lebah berdengung.

Berdasarkan analisis masalah tersebut di atas maka dirumuskan masalah dalam penelitian ini sebagai berikut : Bagaimana cara menerapkan pendekatan komunikatif dan metode lebah berdengung untuk meningkatkan pemahaman siswa dalam mata pelajaran Bahasa Indonesia aspek mendengarkan pada siswa kelas I SD Negeri 10 Mungguk Ibul Semester Ganjil tahun pelajaran 2018/2019?

Penulis melakukan penelitian tindakan kelas ini dengan tujuan untuk: (1) Mendeskripsikan pendekatan komunikatif dalam pembelajaran bahasa Indonesia pada aspek mendengarkan. (2) Mendeskripsikan metode lebah berdengung dalam pembelajaran bahasa Indonesia pada aspek mendengarkan. (3) Mendeskripsikan/ menganalisis dampak penggunaan pendekatan komunikatif dan metode lebah berdengung dalam pembelajaran bahasa Indonesia pada aspek mendengarkan.

Adapun manfaat penelitian tindakan kelas yang dilakukan oleh peneliti dalam pembelajaran Bahasa Indonesia ini adalah : (1) Siswa dapat meningkat pemahamannya, sehingga hasil ketuntasan belajar siswa meningkat. (2) Menemukan permasalahan yang terjadi pada saat proses belajar mengajar. (3) Merumuskan pemecahan masalah pembelajaran yang muncul. (3) Menyusun rencana perbaikan pembelajaran. (4) Dapat mengukur sampai sejauh mana materi yang diajarkan telah dikuasai oleh siswa. (5) Untuk mengetahui kelemahan dan kekurangan dalam menyampaikan materi pelajaran pada siswa. (6) Dapat menentukan cara yang paling efektif dalam mengatasi permasalahan yang terjadi selama pelaksanaan proses belajar mengajar. (7) Melaksanakan perbaikan pembelajaran yang telah direncanakan. (8) Melaporkan hasil perbaikan pembelajaran. (8) Sebagai acuan dalam pelaksanaan kegiatan proses belajar mengajar. (9) Sebagai bahan diskusi dalam kegiatan Kelompok Kerja Guru (KKG) di wilayah kerja penelti.

Bahasa adalah alat komunikasi antar anggota masyarakat yang berupa suara, yang dihasilkan oleh alat ucap manusia dan mengandung makna. Bahasa memeiliki peran sentral dalam perkembangan intelektual, sisial, dan emosional peserta didik dan merupakan penunjang keberhasilan dalam mempelajari semua bidang studi. Pembelajaran bahasa diharapkan membantu peserta didik mengenal dirinya, budayanya, dan budaya orang lain, mengemukakan gagasan dan perasaan, berpartisipasi dalam masyarakat yang menggunakan bahasa tersebut, dan menemukan serta menggunakan kemampuan analitis dan imaginatif yang ada dalam dirinya.

Pembelajaran bahsa Indonesia diarahkan untuk meningkatkan kemampuan peserta didik untuk berkomunikasi dalam bahasa Indonesia dengan baik dan benar, baik secara lisan maupun tulis, serta menumbuhkan apresiasi terhadap hasil karya kesastraan manusia Indonesia.

Pendekatan komunikatif adalah suatu pendekatan yang bertujuan untuk membuat kompetensi komunikatif sebagai tujuan pembelajaran bahasa. Pendekatan komunikatif juga mengembangkan prosedur-prosedur bagi pembelajaran empat ketrampilan berbahasa (menyimak, membaca, berbicara dan menulis), mengakui dan menghargai saling ketergantungan bahasa. 
Tujuan pembelajaran bahasa Indonesia dengan pendekatan komunikatif adalah membentuk kemampuan komunikatif siswa dalam menggunakan bahasa Indonesia yang mencakup empat ketrampilan, baik menyimak, membaca, menulis maupun berbicara.

Ada beberapa bentuk variasi yang bisa dilakukan oleh guru sehubungan dengan penampilannya dalam kegiatan pembelajaran mendongeng. Bentuk-bentuk variasi tersebut antara lain adalah variasi dalam suara, Variasi dalam gerak anggota badan, variasi dalam dalam posisi guru, mimik, kontak pandang, kesenyapan dan pemusatan perhatian.

Metode lebah berdengung merupakan metode mengajar yang digunakan dalam mengajarkan materi dongeng. Dalam pelaksanaannya metode lebah berdengung adalah siswa diberi kebebasan dalam mendongeng dengan teman-temannya, baik dengan teman satu bangku maupun dengan teman satu kelompok. Selama proses mendongeng guru mengamati dan memberi motivasi pada siswa untuk mendongeng bebas tanpa rasa takut kepada temannya.

Guru dituntut dapat sedekat mungkin dengan siswa, sehingga tidak ditakuti oleh siswa, dalam pelaksanaannya bisa di luar kelas maupun di dalam kelas, bila di dalam kelas menjadi gaduh dengan suara-suara siswa mendongeng dengan bebasnya, teman yang diajak mendongeng boleh menambah atau ikut mendongeng untuk membantu ingatan temannya yang sedang mendongeng.

Prosedur metode lebah berdengung yang harus dilakukan dalam pembelajaran adalah ; (1) guru mendongeng dengan menggunakan alat bantu bisa berupa gambar maupun boneka atau alat lain yang dapat menarik perhatian siswa. (2) memberi penjelasan cara mendongeng yang benar dan runtut. (3) pelaksanaan mendongeng bebas dengan teman, guru membimbing dan memberi motivasi pada siswa. (4) siswa disuruh menyebutkan isi dari dongeng yang telah didongengkan oleh guru.

Menurut peneliti kelebihan dari metode ini adalah menjadikan siswa lebih dapat memahami isi dongeng. Keberhasilan pembelajaran Bahasa Indonesia di sekolah dasar salah satunya ditunjang oleh adanya pemilihan dan penggunaan metode pembelajaran yang sesuai dengan karakteristik, dengan pemilihan dan penggunaan metode pembelajaran yang tepat akan memberi pengaruh yang positif terhadap siswa yang peka akhirnya akan meningkatkan pemahaman siswa terhadap materi pembelajaran dan akan dapat meningkatkan prestasi belajar siswa.

Berdasarkan kajian pustaka dan kerangka berfikir seperti tersebut di atas, maka dapat ditarik kesimpulan sementara (hipotesis) sebagai berikut :

"Bahwa penerapan pendekatan komunikatif dan metode lebah berdengung terhadap pelajaran bahasa Indonesia dapat meningkatkan penguasaan siswa pada materi menyebutkan isi dongeng, siswa kelas I SD Negeri 10 Mungguk Ibul Semester Ganjil tahun pelajaran 2018/2019”.

\section{METODE PENELITIAN}

Penelitian ini dilaksanakan di kelas I SD Negeri 10 Mungguk Ibul Semester Ganjil tahun pelajaran 2018/2019 . Pelaksanaannya dilakukan dalam 2 tahap yaitu: Siklus I dilaksanakan pada hari Senin tanggal 1 September 2018. Siklus II dilaksanakan pada hari Kamis tanggal 8 Oktober 2018.

Penelitian Tindakan Kelas dilaksanakan pada mata pelajaran Bahasa Indonesia aspek mendengarkan pada siswa kelas I SD Negeri 10 Mungguk Ibul Semester Ganjil tahun pelajaran 2018/2019. Jumlah siswa keseluruhan 27 siswa. Jumlah siswa laki-laki 14 siswa. Jumlah siswa perempuan 13 siswa. Minat dan semangat belajar siswa rendah. Kondisi ekonomi orang tua siswa ekonomi lemah. Sebagian besar orang tua siswa bekerja sebagai nelayan dan bertani, bekerja seharian, berangkat pagi pulang malam, sehingga siswa tidak mendapat perhatian dari orang tua.

Sumber data dalam penelitian ini hádala siswa kelas I SD Negeri 10 Mungguk Ibul Semester Ganjil tahun pelajaran 2018/2019, teman sejawat sebagai pengamat dan peneliti.

Cara pengumpulan data dengan menggunakan model observasi dan model tes. Data diperoleh dengan observasi yang dilengkapi dengan lembar pengamatan dan diskriptif.

Data penelitian yang peneliti kumpulkan adalah : (1) Tabel pengamatan partisipasi dalam mengikuti proses pembelajaran di dalam kelas. (2) Tabel analisis perolehan nilai hasil ulangan harian.

Instrumen penelitian yang digunakan oleh peneliti sebagai berikut : (1) Rencana pembelajaran yang penulis susun sesuai dengan pendekatan dan metode pembelajaran.. (2) Lembar observasi siswa disusun untuk mengetahui rata-rata tingkat aktivitas siswa, dan dilaksanakan tiap-tiap pertemuan. (3) Lembar observasi guru disusun untuk mengetahui rata-rata tingkat aktivitas guru dalam proses pembelajaran, dan dilaksanakan tiap-tiap siklus. (4) 
Lembar kerja siswa disusun dan diberikan kepada siswa untuk melatih ketrampilan dalam menyelesaikan bentuk-bentuk soal-soal cerita, selain itu digunakan untuk mengetahui tingkat pemahaman siswa dalam menyelesaikan soal. (5) Tes akhir dilaksanakan pada tiap-tiap akhir siklus, yaitu pada pertemuan keempat untuk siklus satu dan pertemuan kedelapan untuk siklus kedua. Hasil dari tes akhir ini digunakan untuk mengukur tingkat ketuntasan belajar.

Prosedur Penelitian Siklus I. Untuk meningkatkan hasil belajar siswa peneliti mencoba melaksanakan Penelitian Tindakan Kelas (PTK). Dalam pelaksanaannya penelitian ini terdiri dari 2 siklus. Masing-masing siklus terdiri dari Rencana, Pelaksanaan, Pengamatan/Pengumpulan data/Instrumen dan Refleksi. (1) Rencana : (a) Pada tahap identifikasi masalah dan perumusan masalah peneliti dibantu oleh teman sejawat dan superior untuk mengungkap dan menperjelas permasalahan yang peneliti hadapi untuk dijadikan jalan pemecahan yang tepat. (b) Merancang pembelajaran dengan menitik beratkan mengganti dongeng pada awal pembelajaran dengan dongeng yang lebih diminati oleh siswa. (c) Menyusun lembar observasi dalam mengobservasi pelaksanaan perbaikan pembelajaran yang difokuskan pada aspek motivasi, keaktifan, kerjasama. (f) Merancang tes formatif. (2) Pelaksanaan Prosedur penelitian tindakan kelas pada siklus I, meliputi : (a) Merencanakan, meliputi, Mengidentifikasi masalah, Menganalisis dan merumuskan masalah, Merencanakan perbaikan. (b) Melakukan tindakan. (c) Megamati. (d)Melakukan refleksi

Untuk mengumpulkan data dan permasalahan serta masukan dalam perbaikan pembelajaran peneliti dibantu oleh seorang pengamat yang disebut teman sejawat. Adapun dalam pelaksanaan pembelajaran/kegiatan belajar mengajar meliputi prosedur sebagai berikut : pra-kegiatan, kegiatan awal, kegiatan inti, kegiatan akhir. Pada kegitan perbaikan pembelajaran siklu I seluruh hipotesis tindakan dilaksanakan secara terpadu, pada akhir siklus pertama hasilnya dianalisis baik yang berupa keberhasilan maupun kegagalan sebagai bahan perkembangan untuk memperbaiki perlakuan yang akan diberikan pada siklus II, demikian seterusnya direncanakan berdasarkan analisis/refleksi pada siklus sebelumnya. (1) Pengamatan/pengumpulan data/instrument. Data penelitian ini diambil dengan pengamatan/pengumpulan data/instrument dengan menggunakan lembar observasi berisi tentang tugas yang dilaksanakan siswa yang meliputi mendongeng kepada teman sebangku, kesungguhan dalam mendongeng, latihan mendongeng dengan inisiatif sendiri. Angket digunakan untuk mencari informasi pelaksanaan pembelajaran yang berisi kesukaan belajar, kepahaman materi, penggunaan alat pembelajaran, bimbingan guru terhadap siswa, penampilan guru dalam mengajar. Guru sebagai subyek penelitian terlibat langsung dalam planning, acting, observing dan reflecting tindakantindakan yang diberikan. (2) Refleksi. Refleksi pada siklus I untuk mengungkapkan keberhasilan maupun untuk mengungkapkan kelemahan pembelajaran, metode mendongeng dengan menggunakan media berupa boneka, digunakan sebagai bahan pertimbangan untuk memperbaiki pembelajaran pada siklus II.

Pelaksanaan Siklus II terdiri dari (1) Rencana Berdasarkan refleksi siklus I peneliti akan memfokuskan penelitian pada pembelajaran guru mendongeng menggunakan media peraga berupa boneka dipadu metode lebah berdengung/ mendongeng bebas. Adapun prosedur pelaksanaan perbaikan pembelajaran secara garis besar sebagai berikut : (a) Mengajukan pertanyaan tentang materi sebelumnya sebagai kegiatan awal. (b) Guru mendongeng di depan kelas dengan gerakan dan mimik yang meyakinkan serta dengan menggunakan alat peraga berupa boneka, sambil mendengarkan siswa mencatat hal-hal penting yang belum dipahami siswa. (c) Siswa menanyakan halhal penting dalam dongeng yang belum mereka pahami. (d) Guru melakukan tanya jawab tentang isi cerita. (e) Siswa diberi kesempatan untuk mendongeng kepada teman sebangku dengan metode lebah berdengung (mendongeng bebas dengan suara jelas). (f) Guru bersama siswa mengulas cara mendongeng yang baik. (g) Guru mengevaluasi secara lesan (mendongeng di depan kelas). (2) Pelaksanaan. Prosedur penelitian tindakan kelas pada siklus II, meliputi : (a) Merencanakan, meliputi, Mengidentifikasi masalah. Menganalisis dan merumuskan masalah. Merencanakan perbaikan. (b) Melakukan tindakan. (c) Mengamati. (e) Melakukan refleksi.

Untuk mengumpulkan data dan permasalahan serta masukan dalam perbaikan pembelajaran peneliti dibantu oleh seorang pengamat yang disebut teman sejawat. Adapun dalam pelaksanaan pembelajaran/ kegiatan belajar mengajar meliputi prosedur sebagai berikut : pra-kegiatan, kegiatan awal, kegiatan inti, kegiatan akhir. Pada kegitan perbaikan pembelajaran siklus II seluruh hipotesis tindakan dilaksanakan secara terpadu, pada akhir 
siklus kedua hasilnya dianalisis untuk direfleksi (1) Pengamatan/pengumpulan data/instrument Data penelitian ini diambil dengan pengamatan/pengumpulan data/instrument dengan menggunakan lembar observasi berisi tentang tugas yang dilaksanakan siswa yang meliputi mendongeng dengan teman sebangku, kesungguhan dalam mendongeng, latihan mendongeng dengan inisiatif sendiri dan bimbingan guru. Angket digunakan untuk mencari informasi pelaksanaan pembelajaran yang berisi kesukaan belajar, kepahaman materi, penggunaan alat pembelajaran, bimbingan guru terhadap siswa, penampilan guru dalam mengajar. Guru sebagai subyek penelitian terlibat

langsung dalam planning, acting, observing dan reflecting tin dakan-tindakan yang diberikan. (2) Refleksi Refleksi pada siklus II untuk mengungkapkan keberhasilan maupun untuk mengungkapkan kelemahan pembelajaran, guru mendongeng dengan menggunakan media boneka dengan dipadu metode lebah berdengung, digunakan sebagai bahan pertimbangan untuk memperbaiki pembelajaran pada siklus selanjutnya atau dihentikan.

\section{HASIL DAN PEMBAHASAN PENELITIAN \\ Deskripsi A wal Pembelajaran}

Pada awal pembelajaran bahasa Indonesia materi "menyebutkan isi dongeng", dari 27 siswa hanya 4 orang siswa yang sudah bisa mendongengkan kembali dongeng yang telah diceritakan guru di depan kelas kepada teman sebangkunya. Hal ini disebabkan karena dongeng yang didongengkan oleh guru kurang diminati oleh siswa.

Hasil tes pembelajaran menyebutkan isi dongeng diperoleh data sebagai berikut : nilai tertinggi yang diperoleh siswa 75 , nilai terendah 30 , dengan nilai rata-rata kelas 54,6 dan tingkat ketuntasan klasikal 14,8\%. Berdasarkan hasil tersebut maka dilakukan Penelitian Tindakan Kelas (PTK) siklus I.

\section{Deskripsi per siklus Siklus I}

Peneliti membuat rencana dan melaksanakan perbaikan pembelajaran siklus I, Guru mengganti deskripsi benda pada awal pembelajaran dengan benda yang diminati dan disukai oleh siswa, seperti binatang.

Dalam melaksanakan pembelajaran siklus I, peneliti dibantu teman sejawat untuk melakukan observasi/ pengamatan terhadap proses belajar mengajar dan pengamatan terhadap siswa dalam pembelajaran. Adapun hasil pengamatan yang dilakukan oleh observer adalah sebagai berikut : Siswa yang mendeskripsikan benda sekitar dengan inisiatif sendiri meningkat dari $12 \%$ menjadi $48 \%$ dari keseluruhan siswa kelas I, Siswa yang mendengarkan pendeskripsian benda sekitar dengan sungguh-sungguh meningkat dari $50 \%$ menjadi 70 $\%$ dan siswa yang mendengarkan penndeskripsian benda sekitar dengan sedang berkurang dari $40 \%$ menjadi $30 \%$, aktivitas siswa dalam belajar mendeskripsikan benda sekitar dengan inisiatif sendiri $40 \%$, dengan bimbingan guru $40 \%$, dan yang diam saja/tidak bersuara $20 \%$.

\section{Hasil Belajar}

Sehingga hasil tes pembelajaran mendongeng diperoleh data sebagai berikut : nilai tertinggi yang diperoleh siswa 90 , nilai terendah 45 , dengan nilai rata-rata kelas 69,6 dan tingkat ketuntasan klasikal $37 \%$. Berdasarkan hasil tersebut maka perbaikan pembelajaran siklus I dilanjutkan dengan melakukan perbaikan pembelajaran siklus II. Dari hasil tes perbaikan pembelajaran siklus I diperoleh nilai :

\section{Tabel 1 . Distribusi Frekwensi Hasil Belajar} Siklus I

\begin{tabular}{cccc}
\hline $\begin{array}{c}\text { Nilai } \\
\left(\mathbf{X}_{\mathbf{1}}\right)\end{array}$ & Tally & $\begin{array}{c}\text { Banyak Siswa } \\
\left(\mathbf{F}_{\mathbf{1}}\right)\end{array}$ & $\mathbf{F}_{\mathbf{1}} \mathbf{X}_{\mathbf{1}}$ \\
\hline 45 & 11 & 1 & 45 \\
\hline 50 & 1 & 0 & 0 \\
\hline 55 & 11111 & 3 & 165 \\
\hline 60 & 11 & 3 & 180 \\
\hline 65 & 11111 & 7 & 455 \\
\hline 70 & 1111 & 3 & 210 \\
\hline 75 & 111 & 3 & 225 \\
\hline 80 & 111 & 3 & 240 \\
\hline 85 & 1 & 0 & 0 \\
\hline 90 & 1 & 4 & 360 \\
\hline Jumlah & & 27 & 1880 \\
\hline
\end{tabular}




\section{Refleksi Siklus I}

Pada siklus I suasana proses pembelajaran terlihat masih kurang aktif, interaksi antara guru dengan siswa sudah terjadi dua arah. Namun demikian pada siklus ini semua siswa memperhatikan deskripsi benda sekitar dengan sungguh-sungguh, namun belum bisa untuk mendongeng sendiri. Dipandang dari sisi guru dalam perbaikan pembelajaran siklus pertama sudah terlihat aktif dan lebih kreatif, mendongeng lepas dari teks dongeng dan berdiri di depan kelas, memotivasi siswa dengan baik. Namun guru masih canggung dalam mendeskripsikan benda sekitar di depan kelas sehingga kelihatan agak kaku.

\section{Siklus II}

Peneliti membuat rencana dan melaksanakan perbaikan pembelajaran siklus II, Guru mendongeng dengan berdiri dengan mimik dan intonasi suara dengan gerakan tubuh, serta disertai media berupa boneka binatang yang disesuaikan dengan dongeng yang sedang didongengkan oleh guru serta dipadu dengan metode lebah berdengung.

\section{Tabel 2. Distribusi Frekwensi Hasil Belajar} Siklus II

\begin{tabular}{cccc}
\hline $\begin{array}{c}\text { Nilai } \\
\left(\mathbf{X}_{\mathbf{1}}\right)\end{array}$ & Tally & $\begin{array}{c}\text { Banyak } \\
\text { Siswa }\left(\mathbf{F}_{\mathbf{1}}\right)\end{array}$ & $\mathbf{F}_{\mathbf{1}} \mathbf{X}_{\mathbf{1}}$ \\
\hline 75 & 1111 & 4 & 300 \\
\hline 80 & 11111 & 10 & 800 \\
& 1111 & & \\
\hline 85 & 111 & 3 & 255 \\
\hline 90 & 111 & 3 & 270 \\
\hline 95 & 111 & 3 & 285 \\
\hline 100 & 1111 & 4 & 400 \\
\hline Jumlah & & 27 & 2310 \\
\hline
\end{tabular}

\section{Refleksi Siklus II}

Kelemahan-kelemahan yang terjadi pada siklus pertama mendorong peneliti untuk berupaya memperbaiki kekurangan. Dari sudut pelaksanaan proses perbaikan pembelajaran pada siklus kedua ini mengalami peningkatan yang cukup signifikan. Suasana proses belajar semakin interaktif, sudah berjalan dua arah antara guru dengan siswa, siswa berani mendongeng dengan teman sebangku dengan suara keras walaupun kelihatan agak gaduh karena peneliti menggunakan metode yang penulis namakan metode lebah berdengung. Hal ini
Dalam melaksanakan pembelajaran siklus II, peneliti dibantu teman sejawat untuk melakukan observasi/pengamatan terhadap proses belajar mengajar dan pengamatan terhadap siswa dalam pembelajaran. Adapun hasil pengamatan yang dilakukan oleh observer adalah sebagai berikut : Siswa yang mendongeng tanpa ditunjuk oleh guru/inisiatif sendiri meningkat menjadi $80 \%$ dari keseluruhan siswa kelas I, Siswa yang mendengarkan dongeng dengan sungguh-sungguh $90 \%$ dan sedang $10 \%$, aktivitas siswa dalam belajar mendongeng dengan inisiatif sendiri $90 \%$, dengan bimbingan guru $10 \%$, semua sudah belajar mendongeng.

\section{Hasil Belajar}

Sehingga hasil tes pembelajaran mendongeng diperoleh data sebagai berikut : nilai tertinggi yang diperoleh siswa 100 , nilai terendah 75 , dengan nilai rata-rata kelas 85,5 dan tingkat ketuntasan klasikal $100 \%$. Berdasarkan hasil tersebut maka perbaikan pembelajaran siklus II dihentikan. Dari hasil tes perbaikan pembelajaran siklus II diperoleh nilai :

berlangsung selama pelaksanaan perbaikan pembelajaran.

Dari sudut guru dalam mengelola kegiatan perbaikan pembelajaran sudah cukup maksimal, guru tidak terpaku pada pola lama guru mendongeng siswa mendengarkan kemudian ganti siswa yang mendongeng, namun lebih mengoptimalkan interaksi siswa dengan guru dan banyak memberi kesempatan dan latihan mendongeng sendiri dengan temannya yang lain.

Pada kegiatan pembelajaran bahasa Indonesia materi menyebutkan isi dongeng, dengan ditugasinya siswa untuk banyak latihan mendongeng dengan teman sebangku maupun yang lain mendorong siswa lebih proaktif tanpa menunggu perintah dari guru. Terhadap siswa yang kurang berani dan kurang pandai guru memberikan bantuan mendongeng ulang tersendiri saat siswa yang lain mendongeng dengan teman yang lain. Kepada siswa yang berani mendongeng tanpa ditunjuk guru, guru juga memberi aplaus atau penghargaan pujian dan acungan jempol.

Berdasarkan hasil diskusi dengan teman sejawat dan refleksi masing-masing siklus dapat di simpulkan indikator penelitian tindakan kelas mata pelajaran bahasa Indonesia materi mengidentifikasi unsur dongeng yang terdiri atas : 1). Guru trampil mengelola proses belajar mengajar bahasa Indonesia khususnya mendongeng, 2). Terjadinya interaksi guru dengan siswa, siswa dengan siswa, 3). Siswa 
sudah bisa menceritakan kembali dongeng guru kepada teman sebangkunya, 4). Tercapainya target tingkat ketuntasan belajar klasikal dapat terwujud walaupun dengan dua siklus.

\section{Pembahasan}

Pada awal pembelajaran guru bercerita dengan duduk sambil membaca buku, pada awalnya siswa mendengarkan cerita dengan sungguh-sungguh namun pada pertengahan guru membaca cerita siswa merasa bosan, dan cenderung bermain sendiri, sehingga saat guru memberikan tugas bercerita banyak siswa yang tidak berani, hanya beberapa siswa yang bisa bercerita ke kepada teman sebangkunya. Hal ini disebabkan karena saat guru bercerita hanya $50 \%$ siswa yang mendengarkan sungguh-sungguh. Pada awal pembelajaran masih banyak siswa yang dalam belajar tidak bersuara/diam saja, tidak dapat mengawali bercerita. Perolehan nilai rata-rata kelas pada awal pembelajaran adalah 54,6. Sehingga perlu diadakan Penelitian Tindakan Kelas (PTK) siklus I.

Pada Siklus I guru mengubah dongeng yang semula pada awal pembelajaran berupa dongeng tentang kerajaan menjadi dongeng tentang binatang yang lebih disukai oleh siswa, sehingga siswa bisa lebih tertarik dan termotivasi dalam pembelajaran. Dalam hal aktivitas belajar bercerita, sudah terjadi penurunan dalam hal yang tidak bersuara atau tidak dapat bercerita dari $36 \%$ menjadi $20 \%$, hal ini dikarenakan siswa termotivasi guru dalam bercerita dan atas bimbingan guru, sehingga sudah banyak yang memiliki inisiatif sendiri bercerita dengan temannya. Sehingga hasil tes menyebutkan isi cerita terjadi kenaikan dari 60,9 menjadi 70,9.

Pada siklus II guru memaksimalkan pembelajaran dengan bercerita dengan menggunakan media pembelajaran berupa boneka binatang yang disesuaikan dengan dongeng yang sedang didongengkan oleh guru dan dipadu dengan metode lebah berdengung/mendongeng bebas dengan teman sebangku maupun dengan teman lain, dalam hal ini kelas kelihatan gaduh namun hal ini menjadikan keunikan tersendiri dalam pembelajaran dan ternyata dengan metode ini pembelajaran menyebutkan isi dongeng di depan kelas berhasil dengan sempurna, dan keberanian siswa dalam bercerita sangat bagus. Aktivitas siswa dalam belajar bercerita dengan inisiatif sendiri meningkat menjadi $80 \%$, hal ini secara lengkap dapat dilihat pada tabel hasil tugas bercerita.

Hasil tes mengidentifikasi unsur cerita dari 27 orang siswa $100 \%$ tuntas dalam pembelajaran dan rata kelas menjadi 85,5.

Adapun hasil angket yang diisi siswa saat awal dan akhir pembelajaran dapat dideskripsikan sebagai berikut : Siswa yang menyenangi pelajaran mendongeng terjadi peningkatan dari $84 \%$ menjadi 96\%. Memahami materi sebelum dan sesudah digunakan metode lebah berdengung $52 \%$ pada awal pembelajaran menjadi 88\%.Yang memanfaatkan kesempatan bertanya pada guru terjadi peningkatan dari $12 \%$ pada awal pembelajaran menjadi $72 \%$, hal ini selengkapnya dapat dilihat pada tabel angket.

Berdasarkan data hasil tes dan diskusi dengan teman sejawat, perbaikan pembelajaran tentang bercerita ada peningkatan pada masing-masing siklus. Baik peningkatan rata-rata prestasi belajar yang cukup signifikan, peningkatan apresiasi siswa terhadap pembelajaran. Berikut ini peneliti sajikan tabel hasil penilaian serta tingkat ketercapaian target sebagai perbandingan pada setiap siklus.

Tabel 3. Perbandingan Hasil Penilaian tiap Siklus.

\begin{tabular}{cccccc}
\hline KBM & Nilai Tertinggi & Nilai Terendah & Rata-rata & $\begin{array}{c}\text { Ketuntasan } \\
\%\end{array}$ & Ket. \\
\hline Awal & 75 & 40 & 54,6 & 14,8 & \\
\hline Siklus I & 90 & 45 & 69,6 & 37 & \\
\hline Siklus II & 100 & 75 & 85,5 & 100 & \\
\hline
\end{tabular}

Pada dasarnya kegiatan pembelajaran adalah suatu proses komunikasi, melalui komunikasi informasi dapat diserap oleh siswa. Namun dalam proses komunikasi terkadang terjadi salah penafsiran pesan. Sebaliknya guru kurang tepat dalam menyampaikan pesan sehingga siswa mengalami kesulitan dalam menerima pesan tersebut. Agar tidak terjadi salah kesesatan, kesalahtafsiran, perlu adanya alat/sarana dan strategi yang tepat dan dapat membantu proses komunikasi dengan siswa pada waktu proses belajar mengajar berlangsung, salah satunya adalah media langsung siswa serta latihan yang berulang-ulang. 


\section{SIMPULAN DAN SARAN \\ Simpulan}

Dari hasil perbaikan pembelajaran yang telah dilaksanakan selama dua siklus, dapat disimpulkan beberapa hal antara lain : (Kemampuan siswa dalam menyebutkan isi dongeng dapat ditingkatkan dengan menggunakan pendekatan komunikatif dan metode lebah berdengung. (1) Meningkatkan minat siswa dalam memahami isi dongeng dapat dilakukan dengan menggunakan metode lebah berdengung yang dipadukan dengan penggunaan media berupa boneka binatang. (2) Perbaikan pembelajaran dapat meningkatkan hasil belajar siswa.

\section{Saran}

Adapun saran yang dapat diberikan penulis adalah sebagai berikut : (1) Kepada Guru : (a) Dalam pembelajaran gunakanlah media pembelajaran yang nyata. (b) Dalam menggunakan metode, carilah metode yang tepat. (c) Dalam menggunakan metode diskusi dan latihan, guru harus menyiapkan soal-soal yang cukup. (de) Gunakan bahasa yang komunikatif. (e) Gunakanlah media pembelajaran yang dapat memotivasi belajar siswa. (2) Bagi Siswa : (a) Siswa harus lebih giat belajar agar hasil belajar dapat meningkat. (b) Siswa harus berani bertanya kepada guru jika ada penjelasan yang kurang jelas. (c) Jangan putus asa bila menemukan soal-soal yang sulit. (3) Kepada Pengambil Kebijakan dalam Pendidikan. (a) Laporan ini dapat dijadikan bahan referensi untuk mengambil keputusan. (b) Laporan ini dapat dijadikan bahan diskusi dalam Kelompok Kerja Guru (KKG). (b) Laporan ini dapat dijadikan pertimbangan dalam pengambilan keputusan.

\section{DAFTAR PUSTAKA}

Ali Muhammad. 2000. Guru dan Proses Belajar Mengajar. Bandung: Sinar Baru Algesindo

Puji santoso,dkk. 2003. Materi dan pembelajaran Bahasa Indonesia SD. Jakarta : Universitas Terbuka

Surakhman, Winarno. 2002. Strategi Belajar Mengajar. Jakarta : PT. Bintang

Wardani, I.G.A.K, Wihardit,K, dan Nasution,N. 2000. Penelitian Tindakan Kelas. Jakarta : Universitas Terbuka

Winkel. 1991. Psikologi Pengajaran. Jakarta: Grasindo

Wahyudin, Dian. 2004. Pengantar Pendidikan. Jakarta : Universitas Terbuka 